\title{
Lipid profile and nutritional status of a pediatric population with sickle cell anemia: differences between gender and association with severity markers
}

\author{
Perfil lipídico e estado nutricional de uma população pediátrica com anemia falciforme: diferenças \\ entre gênero e associação com marcadores de gravidade
}

Perfil lipídico y estado nutricional de una población pediátrica con enfermedad de células

falciformes: diferencias entre sexo y asociación con marcadores de gravedad

Received: 07/31/2021 | Reviewed: 08/05/2021 | Accept: 08/09/2021 | Published: 08/12/2021

\author{
Nilcemar Rodrigues Carvalho Cruz \\ ORCID: https://orcid.org/0000-0003-0820-6604 \\ Universidade Federal de Juiz de Fora, Brasil \\ E-mail: nilcemar.cruz@ufjf.edu.br \\ Thaisa Netto Souza Valente \\ ORCID: https://orcid.org/0000-0002-5708-7325 \\ Universidade Federal de Juiz de Fora, Brasil \\ E-mail: thaisa.netto@ufjf.edu.br \\ Fernanda Oliveira Ferreira \\ ORCID: https://orcid.org/0000-0002-5857-2824 \\ Universidade Federal de Juiz de Fora, Brasil \\ E-mail: fernanda.ferreira@ufjf.edu.br \\ Leandro Roberto de Macedo \\ ORCID: https://orcid.org/0000-0001-6144-7947 \\ Universidade Federal de Juiz de Fora, Brasil \\ Universidade Federal de Juiz de Fora \\ E-mail: leandro.macedo.r@gmail.com \\ Andreza da Silva Brito Rocha \\ ORCID: https://orcid.org/0000-0001-5865-3790 \\ Universidade Federal de Juiz de Fora, Brasil \\ E-mail: andrezabrit@hotmail.com \\ Dayenne Paula Nascimento \\ ORCID: https://orcid.org/0000-0002-5500-2228 \\ Universidade Federal de Juiz de Fora, Brasil \\ E-mail: dayennepaula@ hotmail.com \\ Antônio Frederico de Freitas Gomides \\ ORCID: https://orcid.org/0000-0001-5540-2734 \\ Universidade Federal de Juiz de Fora, Brasil \\ E-mail: frederico.gomides@ufff.edu.br \\ Maria Anete Santana Valente \\ ORCID: https://orcid.org/0000-0002-8914-0493 \\ Universidade Federal de Juiz de Fora, Brasil \\ E-mail: anete.valente@ufjf.edu.br \\ Jacqueline Isaura Alvarez-Leite \\ ORCID: https://orcid.org/0000-0001-6601-9853 \\ Universidade Federal de Minas Gerais, Brasil. \\ E-mail: jalvarezleite@gmail.com \\ Cibele Velloso-Rodrigues \\ ORCID: https://orcid.org/0000-0002-4998-1765 \\ Universidade Federal de Juiz de Fora, Brasil \\ E-mail: cibele.velloso@ufjf.edu.br
}

\begin{abstract}
Objective: To investigate the associations between nutritional status and lipid profile with biomarkers of hemolysis and inflammation in sickle cell anemia, in addition to considering gender differences. Methods: This cross-sectional study analyzed nutritional, and biochemical data of pediatric patients carrying sickle cell anemia. Results: Vitamin A, apolipoprotein B, total cholesterol, low-density lipoprotein, and non-high-density lipoprotein cholesterol were lower in boys. Hemoglobin was significantly lower, and the white blood cells and lactate dehydrogenase were higher in boys. Body mass index, vitamin A, and triglycerides were associated with hemoglobin levels, while apolipoprotein AI was associated with white blood cells and total bilirubin. Additionally, body mass index and vitamin A were associated with lactate dehydrogenase. Vitamin A showed significant predictive power in hemoglobin alteration and lactate dehydrogenase, while apolipoprotein A-I was able to predict high white blood cells values and total bilirubin.
\end{abstract}


Conclusion: This study found in a pediatric population with sickle cell anemia that body mass index, vitamin A, triglycerides, and apolipoprotein A-I were associated with biomarkers of hemolysis and inflammation. Boys exhibited the greater nutritional deficit and severity of the disease.

Keywords: Sickle cell anemia; Dyslipidemias; Apolipoprotein A-I; Nutrition status; Vitamin A; Vitamin D.

\begin{abstract}
Resumo
Objetivo: Investigar as associações entre o estado nutricional e o perfil lipídico com biomarcadores de hemólise e inflamação na anemia falciforme, além de considerar as diferenças de gênero. Métodos: Este estudo transversal analisou dados nutricionais e bioquímicos de pacientes pediátricos com anemia falciforme. Resultados: Vitamina A, apolipoproteína $\mathrm{B}$, colesterol total, lipoproteína de baixa densidade e colesterol de lipoproteína de não alta densidade foram menores em meninos. A hemoglobina foi significativamente menor, e os glóbulos brancos e a desidrogenase láctica foram maiores nos meninos. Índice de massa corporal, vitamina A e triglicerídeos foram associados aos níveis de hemoglobina, enquanto a apolipoproteína A-I foi associada a leucócitos e bilirrubina total. Além disso, o índice de massa corporal e a vitamina $\mathrm{A}$ foram associados à lactato desidrogenase. A vitamina A mostrou poder preditivo significativo na alteração da hemoglobina e desidrogenase láctica, enquanto a apolipoproteína A-I foi capaz de predizer valores elevados de leucócitos e bilirrubina total. Conclusão: Este estudo encontrou em uma população pediátrica com anemia falciforme que o índice de massa corporal, vitamina A, triglicerídeos e apolipoproteína A-I foram associados a biomarcadores de hemólise e inflamação. Os meninos exibiram o maior déficit nutricional e gravidade da doença.
\end{abstract}

Palavras-chave: Anemia falciforme; Dislipidemias; Apolipoproteína A-I; Estado nutricional; Vitamina A; Vitamina D.

\title{
Resumen
}

Objetivo: El objetivo de este artículo es investigar las asociaciones entre el estado nutricional y el perfil lipídico con biomarcadores de hemólisis y inflamación en la ECF, además de considerar diferencias de género. Material y métodos: Este estudio transversal analizó datos nutricionales y bioquímicos de pacientes pediátricos con ECF. Resultados: Vitamina A, apolipoproteína B, colesterol total, LDL-C y colesterol no HDL-C fueron menores en los niños. La hemoglobina fue significativamente menor y los glóbulos blancos (WBC) y desidrogenasa láctica (LDH) fueron mayores en los niños. El escore $\mathrm{Z}$ del índice de masa corporal para edad (escore $\mathrm{z}$ do IMC), vitamina A y triglicéridos fueron asociados a los niveles de hemoglobina, mientras la apolipoproteína A-I fue asociada a leucócitos y bilirrubina total. Además de eso, el escore z del IMC y la vitamina A fueron asociados al LDH. La vitamina A mostro poder predictivo significativo en la alteración de la hemoglobina y LDH, entretanto apolipoproteína A-I fue capaz de predecir valores elevados de leucócitos y bilirrubina total. Conclusión: Este estudio encontró en la población pediátrica con ECF que IMC, vitamina A, triglicéridos y apolipoproteína A-I fueron asociados a biomarcadores de hemólisis y inflamación. Lo niños exhibieron el maior déficit nutricional y gravedad de la enfermedad.

Palabras clave: Enfermedad de células falciformes; Dislipidemias; Apolipoproteína A-I; Estado nutricional; Vitamina A; Vitamina D.

\section{Introduction}

Sickle cell anemia (SCA, MIM\#603903) refers to the homozygous hereditary condition of pathogenic mutation HbS (HBB:c.20A>T; rs334; p.Glu6Val) in the HBB gene (MIM\#141900, loco 11p15.4) (Rees, Williams, \& Gladwin, 2010). SCA affects many people throughout the world, including in Brazil (Wastnedge et al., 2018), where most of the population is of African descent, and causes significant socioeconomic impact mainly in the health system due to morbidity and mortality (Sabarense, Lima, Silva, \& Viana, 2015).

Children with SCA often experience growth delay with a higher prevalence of weight deficit than observed in the general population (Jesus, Konstantyner, Lôbo, \& Braga, 2018; Kazadi, Ngiyulu, Gini-Ehungu, Mbuyi-Muamba, \& Aloni, 2017). Another characteristic frequently observed in SCA is dyslipidemia, characterized by the reduction of serum total cholesterol as well as low-density lipoprotein (LDL-C) (Adegoke, Okeniyi, \& Akintunde, 2016; Teixeira et al., 2019), highdensity lipoprotein (HDL-C) (Teixeira et al., 2019) and increased triglycerides (Adegoke et al., 2016; Teixeira et al., 2019).

Some hematological and biochemical variables are considered severity markers of SCA (Aleluia et al., 2017; GarcíaMorin et al., 2016; Mikobi et al., 2017). While hemoglobin levels are low, the white blood cell count (WBC) (Mikobi et al., 2017), lactate dehydrogenase (LDH), and bilirubin levels, mainly indirect bilirubin, are increased (Aleluia et al., 2017). 
Considering that the deficit physical development (Jesus et al., 2018; Odetunde, Chinawa, Achigbu, \& Achigbu, 2016), changes in lipid profile (Adegoke et al., 2016; Teixeira et al., 2017) and reduced serum levels of some micronutrients (Adegoke, Figueiredo, Adekile, \& Braga, 2017; Martyres et al., 2016) have been observed in the sickle cell disease (SCD), investigating the association of these changes with the severity of the disease could help identify nutritional markers useful in clinical monitoring or to justify the care related to nutritional status by nutritionists and pediatricians. Moreover, some studies have described differences in SCA severity between genders (Esezobor, Akintan, Akinsulie, Temiye, \& Adeyemo, 2016; Odetunde et al., 2016), although these results were inconclusive. Hence, we investigated the association of nutritional status and lipid profile with biomarkers of hemolysis and inflammation in a pediatric population with SCA, considering gender differences.

\section{Methodology}

\section{Study populations}

This is an observational descriptive cross-sectional study design (Hochman, Nahas, Oliveira Filho, \& Ferreira, 2005), which involved demographic, anthropometric, and biochemical data of pediatric patients (aged 5-17 years) carrying stable SCA regardless of hydroxyurea (HU) treatment. It was conducted in an outpatient clinic of the Hemominas Foundation in Minas Gerais State (Brazil) between September 2015 and July 2019. All eligible patients were invited to participate. Exclusion criteria were pregnancy, acute illness, vaso-occlusive crisis (VOC) and blood transfusion in the three months prior to blood collection, as well as the presence of other chronic diseases not related to SCA.

This research was conducted according to the guidelines stated in the Declaration of Helsinki. The study protocol was approved by the Ethics Committees of the Federal University of Juiz de Fora (number 2.146.315) and the Hemominas Foundation (numbers 1.137.657 and 2.521.811).

\section{Sample Size estimation}

To obtain adequate statistical power $(80 \%)$, being conservative and estimating to obtain a moderate correlation (rs around 0.30 ) between the severity hemolytic and inflammatory biomarkers (hemoglobin, WBC, LDH, and total bilirubin) with nutritional status markers (HA z-score, BMI z-score, vitamin A, vitamin D) and lipid profile associations, the sample size necessary for $\mathrm{p}<0.05$ is 68 participants. Considering eventual losses, we estimated to evaluate at least 75 participants in our study to achieve an adequate statistical power (Cohen, 1988; Portney \& Watkins, 2007).

\section{Anthropometric Assessment}

Weight and height were measured using an electronic scale (Líder®, Araçatuba, SP, Brazil) and an anthropometer (Altura Exata ${ }^{\circledR}$, Belo Horizonte, MG, Brazil) with the child wearing light clothes and standing barefoot. Body mass index (BMI) was calculated as weight $(\mathrm{kg}) /$ height $\left(\mathrm{m}^{2}\right)$. Weight and height were transformed into $\mathrm{z}$-scores for height/age (HA z-score) and BMI/age and sex (BMI z-score) and classified using WHO AnthroPlus software (WHO media products, Geneva, Switzerland) (World Health Organization, 2009). Children whose BMI z-score was $<-2$ SD standard deviation (SD) below the mean were classified as underweight (low); $\geq-1$ to $\leq 1 \mathrm{SD}$ as normal weight (acceptable); $>1 \mathrm{SD}$ as overweight or obese (high). Their height was classified as stunted (low) if HA z-score was $<-2$ SD and normal height (acceptable) if HA z-score $\geq$ $-1 \mathrm{SD}$. Values between $-1 \mathrm{EZ}$ and $-2 \mathrm{EZ}$ were considered at risk (borderline) for both anthropometric indexes. 


\section{Biochemical and Hematological Measurements}

After overnight $(8-12$ h) fasting, blood was collected in tubes containing gel separator. Samples were immediately analyzed. Triglycerides, total cholesterol, and high-density lipoprotein cholesterol (HDL-C) were measured using enzymatic kits (Labtest ${ }^{\circledR}$, Lagoa Santa, MG, Brazil), according to the manufacturer's instructions. Non-high-density lipoprotein cholesterol (Non-HDL-C) was obtained by the difference between total cholesterol and HDL-C concentrations. Apolipoprotein A-I (ApoA-I) and apolipoprotein (ApoB) were measured by immunoturbidimetric assays accordingly (Abbott ${ }^{\circledR}$, Chicago, IL, USA). Total and direct bilirubin were directly measured by the Sims/Horn method using enzymatic kits (Labtest ${ }^{\circledR}$, Lagoa Santa, MG, Brazil). Total bilirubin was calculated as the difference between indirect and direct bilirubin. Lactate dehydrogenase (LDH) was measured by the enzymatic colorimetric method according to the manufacturer's instructions. All measurements were performed using the Cobas Mira plus equipment (Roche Diagnostic Systems,Inc., Montclair, NJ, USA). Serum retinol level was measured using high-performance liquid chromatography (HPLC) system with diagnostic reagent (Chromsystems Instruments Chemicals®, Gräfelfing, Germany). Serum vitamin D (25-OHD) levels were analyzed by chemiluminescence microparticle immunoassay (Abbott ${ }^{\circledR}$, Chicago, IL, USA). Hematological data were extracted from medical records. Hemoglobin, $\mathrm{LDH}$, total bilirubin concentrations, and WBC count were used as severity biomarkers. Blood lipid concentrations were classified as proposed by the Expert Panel on Integrated Guidelines for Cardiovascular Health and Risk Reduction in Children and Adolescents (Institute National Heart, Lung and Blood Institute, 2012), that considers the two age groups (below and above 10 years old) for triglycerides and classified into four categories, (acceptable, borderline, low or high) being: Acceptable/high: CT $<170 \mathrm{mg} / \mathrm{dL} / \geq 200 \mathrm{mg} / \mathrm{dL}, \mathrm{LDL}-\mathrm{C}<110 \mathrm{mg} / \mathrm{dL} / \geq 130 \mathrm{mg} / \mathrm{dL}$, Non-HDL-C $<120 \mathrm{mg} / \mathrm{dL} /$ $\geq 145 \mathrm{mg} / \mathrm{dL}$, ApoB $<90 \mathrm{mg} / \mathrm{dL} / \geq 110 \mathrm{mg} / \mathrm{dL}$; and triglycerides $<75 \mathrm{mg} / \mathrm{dL} / \geq 100 \mathrm{mg} / \mathrm{dL}$ (between 0-9 years old) or $<90$ mg/dL/ $\geq 130$ mg/dL ( $\geq 10$ years old); acceptable/low: ApoA-I > 120 mg/dL/ < 115 mg/dL; HDL-C > 45 mg/dL/ < 40 mg/dL. Intermediate values were considered borderline. Triglycerides/HDL-C ratio was calculated from the lipid profile and evaluated as normal values (acceptable) less than 2.0. As we did not find references for children, we used the values for adults (Barbalho et al., 2017). Vitamin A levels were classified as optimal ( $\geq 30 \mu \mathrm{g} / \mathrm{dL})$, suboptimal $(20-29 \mu \mathrm{g} / \mathrm{dL})$, and deficient $(<20 \mu \mathrm{g} / \mathrm{dL})$ (Dougherty et al., 2012). To assess the 25-OHD levels, the deficient ( $\leq 20 \mathrm{ng} / \mathrm{mL}$ ), insufficient $(20.01-29.9 \mathrm{ng} / \mathrm{mL})$, and sufficient ( $\geq 30 \mathrm{ng} / \mathrm{mL}$ ) classifications were used (Jackson, Krauss, Debaun, Strunk, \& Arbeláez, 2012). Optimal and sufficient classifications were considered as "acceptable," suboptimal, and insufficient as "borderline," while deficient was considered "low."

\section{Statistical analysis}

Demographic, anthropometric, biochemical, and hematological data were recorded in a database using IBM SPSS Statistics (version 20; SPSS Inc., Chicago, IL, USA). Shapiro-Wilk statistics were used to test the normality of the distribution. The demographic characteristics of categorical nature are depicted as frequencies and percentages. Furthermore, normally distributed data are presented as the mean and SD, and non-normally distributed data are presented as the median and first/third quartiles. Two-tailed Student's t-test, Mann Whitney test, and the Chi-squared test were performed to compare differences between the two groups. Partial correlation analysis controlling HU was employed to identify relationships between the severity biomarkers hemolytic and inflammatory (hemoglobin, WBC, LDH, and total bilirubin) with nutritional status markers (HA z-score, BMI z-score, vitamin A, vitamin D) and lipid profile. The variables related to the nutritional status and lipid profile that showed a significant correlation with the severity biomarkers $(\mathrm{p} \leq 0.05)$ were selected to conduct multiple linear regression analysis. For the dependent variables that did not present normal distribution, logarithmic transformation was used. The categorical variable HU (use or not use), age, and gender were included in all regression analyses. 
The independent variables that entered the multiple linear regression analysis were also included in the analysis of area under the ROC curve (Receiver Operator Curve) to investigate the accuracy in predicting critical values of interest of the severity biomarkers (hemoglobin, WBC, LDH, and total bilirubin). Cut-off values were set for the $20^{\text {th }}$ of hemoglobin levels $(7.14 \mathrm{~g} / \mathrm{dL})$ and the $80^{\text {th }}$ for WBC $\left(14000 \mathrm{~mm}^{3}\right)$, LDH $(673 \mathrm{U} / \mathrm{L})$, and total bilirubin $(3.37 \mathrm{mg} / \mathrm{dL})$ levels. The statistical significance level was set at $\mathrm{P}<0.05$ and $95 \%$ confidence interval.

\section{Results}

\section{Demographic characteristics and use of hydroxyurea}

Of the total number of children with SCA invited to the study, 22 were excluded for the following reasons: refused participate $(n=5)$, transfusion therapy $(n=13)$, other exclusion criteria $(n=3)$, or death $(n=2)$. Seventy-five children were included in this study, in which $41(54.7 \%)$ were boys. The average age was 11.10 years for boys and 11.82 years for girls. Age and ethnicity were similar between the boys and girls. Eighteen (43.9\%) boys and 21 (61.76\%) girls were on HU therapy, without significant difference between groups $(\mathrm{p}=0.123)$.

\section{Nutritional status, lipid profile, and biomarkers of SCA severity}

Our results showed a high prevalence of patients with a nutritional deficit (low) or nutritional risk (borderline). We found that $60 \%$ of children and adolescents in the study exhibited an adequate nutritional status according to BMI. Considering HA z-score and vitamin A status, less than 50\% was considered adequate (acceptable), and only $10.2 \%$ had adequate 25-OHD levels (Table 1).

Most of the patients had adequate levels of total cholesterol, LDL-C, non-HDL-C, and triglycerides. Nonetheless, HDL-C and ApoA-I levels were low in $64.4 \%$ and $79.5 \%$ of the patients, respectively (Table 1).

Our next step was to analyze the nutritional status and lipid profile, according to gender. The nutritional status markers exhibited no different between females and males, except for the vitamin A levels, which were lower in males. Dyslipidemia characterized by low HDL-C $(<40 \mathrm{mg} / \mathrm{dL})$ was present in both sexes. Nonetheless, ApoB, total cholesterol, LDL-C, and nonHDL-C were higher in girls (Table 2).

Severity biomarkers differed between the two gender groups. Hemoglobin was significantly lower, and WBC and LDH were higher in boys (Table 2).

\section{Regression analyses with severity markers, lipid profile and nutrition status}

The association between severity biomarkers and variables related to nutritional status and lipid profile in children with SCA was analyzed by multiple regression models. Considering multicollinearity, ApoA-I was used preferentially in relation to HDL-C. BMI z-score, and vitamin A were associated positively with hemoglobin and negatively with LDH, while ApoA-I was negatively associated with WBC and bilirubins. Triglyceride's level showed a negative association with hemoglobin (Table 3). 
Table 1 - Nutritional and lipid profile of children with SCA.

\begin{tabular}{|c|c|c|c|c|}
\hline \multirow[t]{2}{*}{ Variables } & Acceptable & Borderline or risk & Low & High \\
\hline & $\%(\mathrm{n})$ & $\%(\mathrm{n})$ & $\%(\mathrm{n})$ & $\%(\mathrm{n})$ \\
\hline \multicolumn{5}{|c|}{ Nutritional Status markers } \\
\hline BMI z-score & $60.0(45)$ & $24.0(18)$ & $10.7(8)$ & $5.3(4)$ \\
\hline HA z-score & $48.0(36)$ & $34.7(26)$ & $17.3(13)$ & \\
\hline Vitamin A & $42.7(29)$ & $44.1(30)$ & $13.2(9)$ & - \\
\hline 25-OHD & $10.2(7)$ & $44.9(31)$ & $44.9(31)$ & - \\
\hline \multicolumn{5}{|c|}{ Lipid profile } \\
\hline ApoA-I & $11.0(8)$ & $9.6(7)$ & $79.4(58)$ & - \\
\hline ApoB & $90.4(66)$ & $9.6(7)$ & - & - \\
\hline Total Cholesterol & $97.3(71)$ & $2.7(2)$ & - & - \\
\hline HDL-C & $19.2(14)$ & $16.4(12)$ & $64.4(47)$ & - \\
\hline LDL-C & $97.3(71)$ & $2.7(2)$ & - & - \\
\hline Triglycerides & $56.2(41)$ & $26.0(19)$ & - & $17.8(13)$ \\
\hline Non-HDL-C & $89.0(65)$ & $9.6(7)$ & - & $1.4(1)$ \\
\hline Triglycerides/HDL-C & $34.2(25)$ & - & - & $65.8(48)$ \\
\hline
\end{tabular}

HA z-score, height-for-age, z-score; BMI z-score, body mass index, z-score; 25-OHD, vitamin D; ApoA-I, apolipoprotein A-I; ApoB, apolipoprotein B; HDL-C, high-density lipoprotein; LDL-C, low-density lipoprotein; Non-HDL-C, non-high-density lipoprotein cholesterol (total cholesterol - HDL-C); triglycerides/HDL-C, triglyceride-to-high-density lipoprotein ratio. Source: Authors.

\section{Analysis of the accuracy of nutritional status and lipid profile in predicting changes in the severity biomarkers in children with SCA}

Analysis with all SCA subjects indicated that vitamin A exhibited significant predictive accuracy in hemoglobin alteration (AUC: 71\%; CI: 0.54-0.88; p = 0.019) and LDH (AUC: 71\%; IC: $0.54-0.88 ; \mathrm{p}=0.021$ ), while ApoA-I was able to predict high values of WBC (AUC: 78\%; CI: 0.66-0.90; $\mathrm{p}=0.003$ ) and total bilirubin (AUC: 82\%; IC: 0.71-0.93; p < 0.001).

Examination of the area under the ROC curve only in subjects who did not use HU showed that vitamin A and ApoA-I remained with significant predictive accuracy in LDH alteration (AUC: 79\%; CI: 0.61-0.97; p = 0.011) and total bilirubin (AUC: 78\%; CI: 0.62-0.94; $\mathrm{p}=0.013$ ), respectively. BMI z-score was significant in predicting hemoglobin alteration (AUC: $75 \%$; CI: $0.57-0.93 ; \mathrm{p}=0.025)$ in this group.

\section{Discussion}

This study showed a high prevalence nutritional deficit or nutritional risk in children with SCA with positive association of BMI z-score and vitamin A with hemolytic marker, hemoglobin, and LDH. In addition, a lipid profile characterized by hypocholesterolemia and predictive power of ApoA-I levels with an inflammation and hemolytic marker, WBC and total bilirubin. 
Table 2 - Comparison of the nutritional status, lipid profile and severity biomarkers average values of children with SCA according to sex.

\begin{tabular}{|c|c|c|c|c|}
\hline Variables & Total & Males & Females & p-value \\
\hline \multicolumn{5}{|c|}{ Nutritional status } \\
\hline BMI z-score & $-0.77(1.05)^{\mathrm{b}}$ & $-0.91(1.05)^{\mathrm{b}}$ & $-0.59(1.03)^{b}$ & 0.196 \\
\hline HA z-score & $-1.01(1.15)^{\mathrm{b}}$ & $-0.92(0.98)^{b}$ & $-1.13(1.33)^{\mathrm{b}}$ & 0.457 \\
\hline Vitamin A $\mu \mathrm{g} / \mathrm{dL}$ & $0.27(0.22-0.34)^{\mathrm{a}}$ & $0.23(0.20-0.29)^{\mathrm{a}}$ & $0.30(0.26-0.40)^{\mathrm{a}}$ & $0.002^{*}$ \\
\hline 25-OHD (ng/mL) $)^{\mathrm{b}}$ & $20.60(17.15-23.15)^{\mathrm{a}}$ & $20.70(17.40-22.95)^{\mathrm{a}}$ & $20.50(16.75-24.95)^{\mathrm{a}}$ & 0.919 \\
\hline \multicolumn{5}{|c|}{ Lipid profile } \\
\hline ApoA-I (mg/dL) & $104.78(12.51)^{\mathrm{b}}$ & $103.60(10.53)^{\mathrm{b}}$ & $106.21(14.60)^{\mathrm{b}}$ & 0.394 \\
\hline ApoB (mg/dL) & $64.64(17.61)^{\mathrm{b}}$ & $58.57(15.31)^{\mathrm{b}}$ & $72.00(17.62)^{b}$ & $0.001^{*}$ \\
\hline Total cholesterol (mg/dL) & $117.00(108.00-143.50)^{\mathrm{a}}$ & $120.07(18.80)^{\mathrm{b}}$ & $132.30(22.66)^{\mathrm{b}}$ & $0.016^{*}$ \\
\hline HDL-C (mg/dL) & $36.00(34.00-42.50)^{\mathrm{a}}$ & $37.0(34.0-44.5)^{\mathrm{a}}$ & $35.0(34.0-41.5)^{\mathrm{a}}$ & 0.494 \\
\hline LDL-C(mg/dL) & $63.60(54.10-82.40)^{\mathrm{a}}$ & $63.3(16.9)^{\mathrm{b}}$ & $76.8(21.6)^{\mathrm{b}}$ & $0.005^{*}$ \\
\hline Triglycerides $(\mathrm{mg} / \mathrm{dL})<10 \mathrm{y}$ & $76.50(57.25-101.50)^{\mathrm{a}}$ & $79.0(55.0-102.0)^{\mathrm{a}}$ & $64.50(51.75-83.75)^{\mathrm{a}}$ & 0.397 \\
\hline Triglycerides $(\mathrm{mg} / \mathrm{dL}) \geq 10 \mathrm{y}$ & $85.00(66.50-111.50)^{\mathrm{a}}$ & $70.0(62.0-122.5)^{\mathrm{a}}$ & $89.0(74.0-113.0)^{\mathrm{a}}$ & 0.248 \\
\hline Non-HDL-C (mg/dL) & $80.00(71.00-101.00)^{\mathrm{a}}$ & $74.5(68.0-93.3)^{\mathrm{a}}$ & $89.0(74.0-109.5)^{\mathrm{a}}$ & $0.010^{*}$ \\
\hline Triglycerides/HDL-C & $2.16(1.85-2.81)^{\mathrm{a}}$ & $2.06(1.56-2.71)^{\mathrm{a}}$ & $2.28(2.04-2.95)^{\mathrm{a}}$ & 0.086 \\
\hline \multicolumn{5}{|c|}{ Severity biomarkers } \\
\hline Hemoglobin $(\mathrm{g} / \mathrm{dL})$, & $8.53(1.59)^{\mathrm{b}}$ & $8.12(1.70)^{\mathrm{b}}$ & $9.01(1.34)^{\mathrm{b}}$ & $0.016^{*}$ \\
\hline $\mathrm{WBC}\left(\mathrm{x} 10^{9} / \mathrm{L}\right)$ & $9.95(4.12)^{\mathrm{b}}$ & $11.41(3.11)^{\mathrm{b}}$ & $9.40(3.50)^{\mathrm{b}}$ & $0.019^{*}$ \\
\hline LDH (U/L) & $551.74(189.26)^{\mathrm{a}}$ & $581.0(452.0-716.0)^{\mathrm{a}}$ & $460.0(387.5-626.5)^{\mathrm{a}}$ & $0.012^{*}$ \\
\hline Total bilirubin (mg/dL) & $2.39(1.36-3.22)^{\mathrm{a}}$ & $2.41(1.54-3.41)^{\mathrm{a}}$ & $2.28(1.27-3.12)^{\mathrm{a}}$ & 0.403 \\
\hline Direct bilirubin (mg/dL) & $0.53(0.17)^{\mathrm{b}}$ & $0.55(0.18)^{\mathrm{b}}$ & $0.52(0,17)^{\mathrm{b}}$ & 0.456 \\
\hline Indirect bilirubin (mg/dL) & $1.77(0.85-2.56)^{\mathrm{a}}$ & $1.83(1.02-3.01)^{\mathrm{a}}$ & $1.65(0.82-2.46)^{\mathrm{a}}$ & 0.350 \\
\hline
\end{tabular}

HA z-score, height-for-age, z-score; BMI z-score, body mass index, z-score; 25-OHD, vitamin D; ApoA-I, apolipoprotein A-I; ApoB, apolipoprotein B; HDL-C, high-density lipoprotein; LDL-C, low-density lipoprotein; Non-HDL-C, non-high-density lipoprotein cholesterol (total cholesterol- HDL-C); y, years old; triglycerides/HDL-C, triglyceride-to-high-density lipoprotein ratio; WBC, white blood cells; LDH, lactate dehydrogenase. ${ }^{a}$ analyzed by Mann-Whitney U-test and expressed as median (quartiles 1 and 3). ${ }^{b}$ Analyzed by independent sample ttest and expressed as mean (standard deviation). "indicates statistical significance, $\mathrm{p}<0.05$. Source: Authors.

Dyslipidemia has been considered one of the sub-phenotypes in SCD (Adegoke et al., 2016; Akinlade et al., 2014; Teixeira et al., 2019; Valente-Frossard et al., 2020). We observed that dyslipidemia was frequent in our patients (64.4\%). The levels of ApoA-I, HDL-C, triglycerides, and triglycerides/HDL-C ratio did not differ between genders. However, ApoB, total cholesterol, LDL-C, and non-HDL-C levels were lower in boys. A study observed in the adult population with SCA, lower levels of total cholesterol, LDL-C, non-HDL-C, HDL-C, and ApoA-I in men than women (Lalanne-Mistrih et al., 2018), and hypocholesterolemia was also reflected in hemolysis and inflammation biomarkers. Boys exhibited worse levels of hemolysis and inflammation biomarkers than girls. This confirms the findings in other populations, in both steady-state and vasoocclusive crisis in SCA, with a proportional relationship between anemia severity and hypocholesterolemia (Akinlade et al., 2014; Ephraim et al., 2016; Teixeira et al., 2019). 
Table 3 - Summary of simultaneous regression analyses predicting severity biomarkers in children with SCA.

\begin{tabular}{|c|c|c|c|c|}
\hline Variable & Coefficient & SE (B) & $\mathrm{CI}$ & p-value \\
\hline \multicolumn{5}{|c|}{ Hemoglobin $-R^{2}=0.33$} \\
\hline Constant & 7.82 & 0.667 & $(6.495 ; 9.163)$ & $<0.001$ \\
\hline BMI z-score & 0.336 & 0.162 & $(0.011 ; 0.660)$ & $0.043^{*}$ \\
\hline Vitamin A & 5.333 & 1.800 & $(1.732 ; 8.934)$ & $0.004^{*}$ \\
\hline Triglycerides & -0.010 & 0.004 & $(-0.019 ;-0.002)$ & $0.018^{*}$ \\
\hline Hydroxyurea & 0.722 & 0.347 & $(0.027 ; 1.416)$ & $0.042^{*}$ \\
\hline \multicolumn{5}{|c|}{$W B C-R^{2}=0.30$} \\
\hline Constant & 21585.03 & 3067.322 & $(15445.11 ; 27724.94)$ & $<0.001$ \\
\hline ApoA-I & -93.94 & 29.737 & $(-153.465 ;-34.416)$ & $0.003^{*}$ \\
\hline Hydroxyurea & -2262.55 & 768.816 & $(-3801.507 ;-723.601)$ & $0.005^{*}$ \\
\hline \multicolumn{5}{|c|}{$L D H-R^{2}=0.31$} \\
\hline Constant & 747.957 & 64.437 & $(619.230 ; 876.684)$ & 0.000 \\
\hline BMI z-score & -44.758 & 18.790 & $(-82.295 ;-7.221)$ & $0.020^{*}$ \\
\hline Vitamin A & -579.098 & 208.973 & $(-996.570 ;-161.626)$ & $0.007^{*}$ \\
\hline Hydroxyurea & -125.692 & 39.921 & $(-205.443 ;-45.941)$ & $0.002^{*}$ \\
\hline \multicolumn{5}{|c|}{ Total bilirubin ${ }^{I}-R^{2}=0.40$} \\
\hline Constant & 6.974 & 1.195 & $(4.589 ; 9.359)$ & $<0.001$ \\
\hline ApoA-I & -0.035 & 0.012 & $(-0.058 ;-.012)$ & $0.004^{*}$ \\
\hline Hydroxyurea & -1.485 & 0.288 & $(-2.059 ;-0.911)$ & $<0.001^{*}$ \\
\hline
\end{tabular}

CI, confidence interval; BMI z-score, body mass index Z score; WBC, white blood cells; ApoA-I, apolipoprotein A-I; LDH, lactate dehydrogenase. Variables that entered each analysis: Hemoglobin - BMI z-score, vitamin A, ApoA-I and triglycerides; LDH - BMI z-score, vitamin A; WBC - BMI z-score, ApoA-I, and triglycerides; total bilirubin - ApoA-I. Hydroxyurea, gender, and age were included in all the analyses, but only the hydroxyurea was present in the model. ${ }^{1}$ Levels of total bilirubin were log-transformed. ${ }^{*}$ Indicates statistical significance, $\mathrm{p}<0.05$. Source: Authors.

In our study, ApoA-I was negatively associated and a predictor of WBC and total bilirubin in the ROC curve. ApoA-I is the main protein in the HDL-C particle and responsible for stimulating reverse cholesterol transport, removing the excess from the tissues, and redirecting it to the liver. It may also inhibit the oxidation of LDL-C, assist in removing toxic products, and exhibit anti-inflammatory properties (Navab, Reddy, Van Lenten, \& Fogelman, 2011).

Almost half of the individuals evaluated exhibited elevated or borderline triglycerides levels. Triglycerides levels were inversely correlated with hemoglobin level (Mokondjimobe et al., 2012; Valente-Frossard et al., 2020). Increased triglycerides in SCA subjects has previously been demonstrated (Teixeira et al., 2019). A study involving an SCD adult population identified a correlation between higher triglycerides levels and a lower hemoglobin level, higher levels of LDH, arginase, and inflammatory biomarkers, and vascular dysfunction (Zorca et al., 2010). The mechanisms explaining the elevated triglycerides in SCD are not fully understood. More recently, studies have indicated the involvement of angiopoietin-like proteins (ANGPTL) (Hassan, 2017; Zhang, 2016). ANGPTL3, ANGPTL4, and ANGPTL8 (Kersten, 2017; Li \& Teng, 2014) inhibit lipoprotein lipase (LPL) activity that, in turn, reduces the triglycerides clearance. Sickle cell hemolysis is believed to generate byproducts that may stimulate the hepatic production of ANGPLT3 and ANGPTL4. Higher ANGPTL3 and ANGPTL4 were observed in adults with SCA compared to the control group (Vendrame, Olops, Saad, Costa, \& Fertrin, 2019).

Children with SCA have a more significant nutritional deficit compared to control group (Jesus et al., 2018; Kazadi et al., 2017; Odetunde et al., 2016). Furthermore, differences in nutritional status between girls and boys have been reported, with a greater body mass deficit in boys (Esezobor et al., 2016; Odetunde et al., 2016). Our SCA population displayed lower levels 
of vitamin A in boys, similar to the result found in American children with SCA (Schall, Zemel, Kawchak, Ohene-Frempong, \& Stallings, 2004). In SCA, the prevalence of suboptimal/deficient vitamin A status is high (Brownell et al., 2020; Dougherty et al., 2012). Vitamin A exerts a potent antioxidant effect (Baydas et al., 2002). Sickle cells are more susceptible to oxidative stress (Vona et al., 2021), which seems to be associated with the aseptic inflammatory profile in these individuals (Biswal et al., 2018). Therefore, there is greater demand for vitamin A for neutralization in SCD (Behera, Dixit, Bulliyya, \& Kar, 2012). Additionally, hepatic stellate cells are primarily responsible for the storage of vitamin A, and in case of liver damage, these cells are activated with rapid loss of vitamin A stock (Blaner et al., 2009). Individuals with SCD are exposed to chronic liver injury (Praharaj \& Anand, 2021), which associated with more significant oxidative stress could partially explain the high frequency of low levels of vitamin A. Therefore, it is possible to understand the more pronounced profile of hemolysis and inflammation in boys, indicated by lower hemoglobin, leukocytes, and LDH, concomitant with lower levels of vitamin A. Thus, an inadequate vitamin A status could aggravate the disease or be a consequence of it.

We also identified that BMI z-score and vitamin A levels were positively associated with hemoglobin and inversely with LDH. Similarly, vitamin A showed the predictive power of hemoglobin and LDH levels in SCA subjects. In other studies, lower levels of hemoglobin (Behera et al., 2012; Schall et al., 2004), as well as a higher frequency of hospitalization (Schall et al., 2004), percentage of falcization, and WBC (Behera et al., 2012), were observed in lower levels of vitamin A.

The high prevalence of 25-OHD deficiency observed in our population was also reported in studies with SCD children (Adegoke, Braga, Adekile, \& Figueiredo, 2017; Oztas, Unal, Eskandari, Tamer, \& Ozgunes, 2018) and appears to be influenced by ethnicity (Adegoke, Braga, et al., 2017). The vitamin D intake by Brazilian children below the daily recommendation seems to be another important factor (Filgueiras, Suhett, Silva, Rocha, \& Novaes, 2018). However, the present study does not provide this analysis. There was no difference in vitamin D levels between boys and girls. Although some studies indicate higher levels of vitamin D in boys (Alyahya, 2017; Lee, Licursi, \& McMahon, 2015), our results are in agreement with Adegoke, Braga et al (2017), which investigated SCA children from 4 to 11 years of age. The vitamin D was not correlated with biomarkers of hemolysis and inflammation in our SCA patients. However, the benefit of vitamin D in the prevention of clinical abnormality in SCD is known. For every ten units of increase in levels of this vitamin, there was a $46 \%$ reduction in the probability of having acute pain in children and adolescents 3 to 20 years old with SCD (Lee et al., 2015).

This study is limited by its cross-sectional design, making it difficult to understand better the relationship between nutritional status and lipid profile and SCA severity. The size of the population of a single hematology care center also limits the generalization of results. However, our study showed an effort by including all patients with SCA treated at the study site, with a low percentage of rejection. In the analysis of vitamin D status, the season was not considered; however, blood collection occurred in all seasons.

\section{Conclusion}

Our findings present the relationship between nutritional status and lipid profile with severity biomarkers of SCA in a pediatric population. The observed results reinforce the need to consider nutritional assessment, including analysis of the lipid profile, in the follow-up of children with SCA. The study shows that lower levels of vitamin A; higher hemolytic and inflammatory patterns; and hypocholesterolemia, are more prominent in boys. Thus, gender is one of the confounding factors and should always be consider in the analysis of the associations of these markers.

Additional and prospective studies that could follow children until adulthood are suggested to verify any long-term reflections in clinical severity of SCA due to their nutritional and lipid profile. 


\section{Acknowledgments}

We are grateful to the participating families, children, and students who participated in the survey for their cooperation. We thank all the professionals of the Hemominas Foundation of Governador Valadares/Minas Gerais, Brazil.

This work was supported by Fundação de Amparo à Pesquisa do Estado de Minas Gerais (FAPEMIG; www.fapemig.br); Ministry of Health of Brazil and National Council for Scientific and Technological Development (CNPq; http://www.cnpq.br/) under Grant number: CDS/APQ 03522/13; Financier of Studies and Projects (FINEP; http://www.finep.gov.br) under Grant number: 633/13; Pró-Reitoria de Pesquisa e Pós-graduação (PROPP-UFJF) under Grants numbers ID41977/2017-2018 and ID38723/2016-2017 and Pró-Reitoria de Extensão (PROEX-UFJF) under Grant number $1861 / 2018-2019$.

\section{References}

Adegoke, S. A., Braga, J. A. P., Adekile, A. D., \& Figueiredo, M. S. (2017). Impact of Hydroxyurea on anthropometry and serum 25-hydroxyvitamin D among children with sickle cell disease. Journal of Pediatric Hematology/Oncology, 40(4), 243-247.

Adegoke, S. A., Figueiredo, M. S., Adekile, A. D., \& Braga, A. P. (2017). Comparative study of the growth and nutritional status of Brazilian and Nigerian school-aged children with sickle cell disease. Int Health, 9, 327-334. https://doi.org/10.1093/inthealth/ihx035

Adegoke, S. A., Okeniyi, J. A. O., \& Akintunde, A. A. (2016). Electrocardiographic abnormalities and dyslipidaemic syndrome in children with sickle cell anaemia. Cardiovascular Journal of Africa, 27(1), 16-20. https://doi.org/10.5830/CVJA-2015-059

Akinlade, K. S., Adewale, C. O., Rahamon, S. K., Fasola, F. A., Olaniyi, J. A., \& Atere, A. D. (2014). Defective lipid metabolism in sickle cell anaemia subjects in vaso-occlusive crisis. Nigerian Medical Journal, 55(5), 428-431. https://doi.org/10.4103/0300-1652.140388

Aleluia, M. M., Guarda, C. C., Santiago, R. P., Fonseca, T. C. C., Neves, F. I., Souza, R. Q., Larissa Alves Farias, L. A., Pimenta, F. A., Fiuza, L. M., Pitanga, T. N., Ferreira, J. R. D. Adorno, E. V., Cerqueira, B. A. V., Gonçalves, M. de S. (2017). Association of classical markers and establishment of the dyslipidemic sub-phenotype of sickle cell anemia. Lipids in Health and Disease, 16(74), 1-9. https://doi.org/10.1186/s12944-017-0454-1

Alyahya, K. O. (2017). Vitamin D levels in schoolchildren: A cross-sectional study in Kuwait. BMC Pediatrics, 17(1), 1-10. https://doi.org/10.1186/s12887017-0963-0

Barbalho, S. M., Oshiiwa, M., Sato Fontana, L. C., Ribeiro Finalli, E. F., Paiva Filho, M. E., \& Machado Spada, A. P. (2017). Metabolic syndrome and atherogenic indices in school children: A worrying panorama in Brazil. Diabetes and Metabolic Syndrome: Clinical Research and Reviews, 11(2016), S397S401. https://doi.org/10.1016/j.dsx.2017.03.024

Baydas, G., Karatas, F., Gursu, M. F., Bozkurt, H. A., Ilhan, N., Yasar, A., \& Canatan, H. (2002). Antioxidant vitamin levels in term and preterm infants and their relation to maternal vitamin status. Archives of Medical Research, 33(3), 276-280. https://doi.org/10.1016/S0188-4409(02)00356-9

Behera, S., Dixit, S., Bulliyya, G., \& Kar, S. K. (2012). Vitamin a status and hematological values in sickle cell disorder cases. Indian Journal of Medical Sciences, 66(7), 169. https://doi.org/10.4103/0019-5359.114180

Biswal, S., Rizwan, H., Pal, S., Sabnam, S., Parida, P., \& Pal, A. (2018). Oxidative stress, antioxidant capacity, biomolecule damage, and inflammation symptoms of sickle cell disease in children. Hematology, 24(1), 1-9. https://doi.org/10.1080/10245332.2018.1498441

Blaner, W. S., O’Byrne, S. M., Wongsiriroj, N., Kluwe, J., D’Ambrosio, D. M., Jiang, H., Schwabe, R. F., Hillman, E. M. C., Piantedosi, R., Libien, J. (2009). Hepatic stellate cell lipid droplets: A specialized lipid droplet for retinoid storage. Biochimica et Biophysica Acta, 1791(6), 467-473. https://doi.org/10.1016/j.bbalip.2008.11.001

Brownell, J. N., Schall, J. I., Mcanlis, C. R., Smith-Whitley, K., Norris, C. F., \& Stallings, V. A. (2020). Effect of high-dose vitamin A supplementation in children with sickle cell disease. Journal of Pediatric Hematology/Oncology, 42(2), 83-91. https://doi.org/10.1097/MPH.0000000000001673

Cohen, J. (1988) Statistical Power Analysis for the Behavioral Sciences (2nd ed.) New York: Lawrence Erlbaum Associates.

Dougherty, K. A, Schall, J. I., Kawchak, D. A, Green, M. H., Ohene-frempong, K., Zemel, B. S., \& Stallings, V. A. (2012). No improvement in suboptimal vitamin A status with a randomized, double-blind, placebo-controlled trial of vitamin A supplementation in children with sickle cell disease. The American Journal Clinical Nutrition, 96, 932-940. https://doi.org/10.3945/ajcn.112.035725

Ephraim, R. K. D., Adu, P., Ake, E., Agbodzakey, H., Adoba, P., Cudjoe, O., \& Agoni, C. (2016). Normal Non-HDL Cholesterol, Low Total Cholesterol, and HDL Cholesterol Levels in Sickle Cell Disease Patients in the Steady State: A Case-Control Study of Tema Metropolis. Journal of Lipids, 2016, 1-5. https://doi.org/10.1155/2016/7650530

Esezobor, C. I., Akintan, P., Akinsulie, A., Temiye, E., \& Adeyemo, T. (2016). Wasting and stunting are still prevalent in children with sickle cell anaemia in Lagos , Nigeria. Italian Journal of Pediatrics, 42, 1-8. https://doi.org/10.1186/s13052-016-0257-4

Filgueiras, M. D. S., Suhett, L. G., Silva, M. A., Rocha, N. P., \& Novaes, J. F. De. (2018). Lower vitamin D intake is associated with low HDL cholesterol and vitamin D insufficiency / deficiency in Brazilian children. 25, 1-9. https://doi.org/10.1017/S1368980018000204 
García-Morin, M., López-Sangüos, C., Vázquez, P., Alvárez, T., Marañón, R., Huerta, J., \& Cela, E. (2016). Lactate Dehydrogenase: A Marker of the Severity of Vaso-Occlusive Crisis in Children with Sickle Cell Disease Presenting at the Emergency Department. Hemoglobin, 40(6), 388-391. https://doi.org/10.1080/03630269.2016.1275677

Hassan, M. (2017). ANGPLT3: A novel modulator of lipid metabolism. Global Cardiology Science and Practice, 2017(1), 1-7. https://doi.org/10.21542/gcsp.2017.6

Hochman, B., Nahas, F. X., Oliveira Filho, R. S., Ferreira, L. M. (2005). Desenhos de pesquisa. Acta Cirúrgica Brasileira, 20(Suppl. 2), 2-9. https://doi.org/10.1590/S0102-86502005000800002

Institute National Heart Lung and Blood Institute. Expert panel on integrated guidelines for cardiovascular health and risk reduction in children and adolescents: summary report. (pp. 4-83). (2012). https://doi.org/10.1542/peds.2009-2107C

Jackson, T. C., Krauss, M. J., Debaun, M. R., Strunk, R. C., \& Arbeláez, A. M. (2012). Vitamin D deficiency and comorbidities in children with sickle cell anemia. Pediatric Hematology and Oncology, 29(3), 261-266. https://doi.org/10.3109/08880018.2012.661034

Jesus, A. C. S., Konstantyner, T., Lôbo, I. K. V., \& Braga, J. A. P. (2018). Socioeconomic and nutritional characteristics of children and adolescents with sickle cell anemia: A systematic review. Revista Paulista de Pediatria, 36(4), 491-499. https://doi.org/10.1590/1984-0462/;2018;36;4;00010

Kazadi, A. L., Ngiyulu, R. M., Gini-Ehungu, J. L., Mbuyi-Muamba, J. M., \& Aloni, M. N. (2017). Factors associated with growth retardation in children suffering from sickle cell anemia: First report from central Africa. Anemia, 2017. https://doi.org/https://doi.org/10.1155/2017/7916348

Kersten, S. (2017). Angiopoietin-like 3 in lipoprotein metabolism. Nature Reviews Endocrinology, 13(12), 731-739. https://doi.org/10.1038/nrendo.2017.119

Lalanne-Mistrih, M.-L., Connes, P., Lamarre, Y., Lemonne, N., Hardy-Dessources, M.-D., Tarer, V., Etienne-Julan, M., Mougenel, D., Tressières, B., \& Romana, M. (2018). Lipid profiles in French West Indies sickle cell disease cohorts, and their general population. Lipids in Health and Disease, 17(1), 38. https://doi.org/10.1186/s12944-018-0689-5

Lee, M. T., Licursi, M., \& McMahon, D. J. (2015). Vitamin D deficiency and acute vaso-occlusive complications in children with sickle cell disease. Pediatric Blood Cancer, 62, 643-647. https://doi.org/10.1002/pbc.25399

Li, Y., \& Teng, C. (2014). Angiopoietin-like proteins 3, 4 and 8: Regulating lipid metabolism and providing new hope for metabolic syndrome. Journal of Drug Targeting, 22(8), 679-687. https://doi.org/10.3109/1061186X.2014.928715

Martyres, D. J., Vijenthira, A., Barrowman, N., Harris-Janz, S., Chretien, C., \& Klaassen, R. J. (2016). Nutrient insufficiencies/deficiencies in children with sickle cell disease and its association with increased disease severity. Pediatric Blood Cancer, 63(6), 1060-1064. https://doi.org/10.1002/pbc.25940

Mikobi, T. M., Tshilobo, P. L., Aloni, M. N., Akilimali, P. Z., Mvumbi-Lelo, G., \& Mbuyi-Muamba, J. M. (2017). Clinical phenotypes and the biological parameters of Congolese patients suffering from sickle cell anemia: A first report from Central Africa. $J$ Clin Lab Anal, 31(6), 1-6. https://doi.org/10.1002/jcla. 22140

Mokondjimobe, É., Longo-Mbenza, B., Ovono-Abessolo, F., Gombet, T., Guie, G., Ngou-Milama, E., \& Parra, H. J. (2012). Évaluation du profil lipoprotéique et du risque athérogène chez les drépanocytaires homozygotes et hétérozygotes de Brazzaville. Annales de Biologie Clinique, 70(2), 183-188. https://doi.org/10.1684/abc.2012.0687

Navab, M., Reddy, S. T., Van Lenten, B. J., \& Fogelman, A. M. (2011). HDL and cardiovascular disease: Atherogenic and atheroprotective mechanisms. Nature Reviews Cardiology, 8(4), 222-232. https://doi.org/10.1038/nrcardio.2010.222

Odetunde, O. I., Chinawa, J. M., Achigbu, K. I., \& Achigbu, E.O. (2016). Body Mass Index and other anthropometric variables in children with sickle cell anaemia. Pakistan Journal of Medical Sciences, 32(2), 341-346.

Oztas, Y., Unal, S., Eskandari, G., Tamer, L., \& Ozgunes, N. (2018). Vitamin D deficiency and its association with inflammatory markers, lipid profile and regulatory $\mathrm{t}$-cells in pediatric sickle cell disease patients. Indian Journal of Hematology and Blood Transfusion, 34(3), 480-485. https://doi.org/10.1007/s12288-017-0890-0

Praharaj, D. L., \& Anand, A. C. (2021). Sickle Hepatopathy. Journal of Clinical and Experimental Hepatology, 11(1), 82-96. https://doi.org/10.1016/j.jceh.2020.08.003

Rees, D. C., Williams, T. N., \& Gladwin, M. T. (2010). Sickle-cell disease. The Lancet, 376(9757), 2018-2031. https://doi.org/10.1016/S0140$6736(10) 61029-\mathrm{X}$

Portney, L.G., \&Watkins, M.P. (2007). Foundations of Clinical Research: Applications to Practice. Pearson (3rd ed.). Upper Saddle River, N.J: Pearson/Prentice Hall.

Sabarense, A. P., Lima, G. O., Silva, L. M. L., \& Viana, M. B. (2015). Characterization of mortality in children with sickle cell disease diagnosed through the Newborn Screening Program. Jornal de Pediatria (Versão Em Português), 91(3), 242-247. https://doi.org/10.1016/j.jpedp.2015.03.009

Schall, J. I., Zemel, B. S., Kawchak, D. A., Ohene-Frempong, K., \& Stallings, V. A. (2004). Vitamin A status, hospitalizations, and other outcomes in young children with sickle cell disease. Journal of Pediatrics, 145(1), 99-106. https://doi.org/10.1016/j.jpeds.2004.03.051

Steinberg, M. H. (2008). Sickle cell anemia, the first molecular disease: Overview of molecular etiology, pathophysiology, and therapeutic approaches. The Scientific World Journal, 8, 1295-1324. https://doi.org/10.1100/tsw.2008.157

Teixeira, R. S., Arriaga, M. B., Terse-Ramos, R., Ferreira, T. A., Machado, V. R., Rissatto-Lago, M. R., Silveira, P. S., Boa-Sorte, N., Ladeia, A. M. T., \& Andrade, B. B. (2019). Higher values of triglycerides:HDL-cholesterol ratio hallmark disease severity in children and adolescents with sickle cell anemia. Brazilian Journal of Medical and Biological Research, 52(10), e8833. https://doi.org/10.1590/1414-431X20198833 
Research, Society and Development, v. 10, n. 10, e344101018934, 2021

(CC BY 4.0) | ISSN 2525-3409 | DOI: http://dx.doi.org/10.33448/rsd-v10i10.18934

Teixeira, R. S., Terse-Ramos, R., Ferreira, T. A., Machado, V. R., Perdiz, M. I., Lyra, I. M., Nascimento, V. L., Boa-Sorte, N., Andrade, B B., \& Ladeia, A. M. (2017). Associations between endothelial dysfunction and clinical and laboratory parameters in children and adolescents with sickle cell anemia. Plos One, 12(9), 1-14. https://doi.org/10.1371/journal.pone.0184076

Valente-Frossard, T. N. S., Cruz, N. R. C., Ferreira, F. O., Belisário, A. R., Pereira, B. M., Gomides, A. F. F., Resende, G. A. D., Carlos, A. M., MoraesSouza, H., \& Velloso-Rodrigues, C. (2020). Polymorphisms in genes that affect the variation of lipid levels in a Brazilian pediatric population with sickle cell disease : rs662799 APOA5 and rs964184 ZPR1. Blood Cells, Molecules and Diseases, 80(102376). https://doi.org/10.1016/j.bcmd.2019.102376

Vendrame, F., Olops, L., Saad, S. T. O., Costa, F. F., \& Fertrin, K. Y. (2019). Hypocholesterolemia and dysregulated production of angiopoietin-like proteins in sickle cell anemia patients. Cytokine, 120, 88-91. https://doi.org/10.1016/j.cyto.2019.04.014

Vona, R., Sposi, N. M., Mattia, L., Gambardella, L., Straface, E., \& Pietraforte, D. (2021). Sickle cell disease: Role of oxidative stress and antioxidant therapy. Antioxidants, 10(2), 1-27. https://doi.org/10.3390/antiox 10020296

Wastnedge, E., Waters, D., Patel, S., Morrison, K., Goh, M. Y., Adeloye, D., \& Rudan, I. (2018). The global burden of sickle cell disease in children under five years of age: A systematic review and meta-analysis. Journal of Global Health, 8(2), 1-9. https://doi.org/10.7189/jogh.08.021103

World Health Organization. (2009). Software for assessing growth of the worlds children and adolescents. In Who Antro Plus for Personal Computers Manual.

Zhang, R. (2016). The ANGPTL3-4-8 model, a molecular mechanism for triglyceride trafficking. Open Biology, 6(4), 1-11. https://doi.org/10.1098/rsob.150272

Zorca, S., Freeman, L., Hildesheim, M., Allen, D., Remaley, A. T., Taylor, J. G., \& Kato, G. J. (2010). Lipid levels in sickle-cell disease associated with haemolytic severity, vascular dysfunction and pulmonary hypertension. British Journal of Haematology, 149(3), 436-445. https://doi.org/10.1111/j.13652141.2010.08109.x 